\title{
Önkormányzati sportügyek - A helyi önkormányzatok sporttal kapcsolatos feladatainak önkormányzati tulajdonban lévő gazdasági társaságok útján történő ellátása az Állami Számvevőszék ellenörzései tükrében \\ Municipal sports affairs - Carrying out the tasks of local governments in relation to sport through municipally owned companies in the light of the audits of the State Audit Office
}

\section{Boros Anita1, Zimányi Róbert G. ${ }^{2}$, Géczi Gábor³}

1 Széchenyi István Egyetem, Globalizációs Kompetencia Központ

2 Evopro Systems Engineering Kft.

3 Testnevelési Egyetem, Sportmenedzsment Tanszék

\begin{abstract}
Absztrakt - Magyarországon az állampolgárok sportolása nagymértékben kötődik a helyi önkormányzatok tevékenységéhez, hiszen a 3178 önkormányzat (Központi Statisztikai Hivatal, KSH, 2019) saját erejéhez mérten helyi rendeletekkel, jelentős támogatásokkal és nem utolsó sorban a létesítmények fenntartásával biztosítja az Alaptörvény XX. cikkében is nevesített testi és lelki egészséghez való jogot a sportolás és a rendszeres testedzés támogatása érdekében. A sportügyek ellátását az önkormányzatok általában háttérintézményekben, saját tulajdonú gazdasági társaságok útján oldják meg, amelyek szabályszerú múködése az állam és az önkormányzatok, és leginkább az állampolgárok érdeke. Tanulmányunk - az Állami Számvevőszék vizsgálati jelentései alapján - az egyes hazai önkormányzatok sportügyeivel foglalkozó társaságainak múködését elemzi.
\end{abstract}

Kulcsszavak: önkormányzatok, sportügyek, Állami Számvevőszék, közfeladatellátás, háttérintézmény, önkormányzati tulajdonú gazdasági társaságok

Abstract - In Hungary, sports activity of citizens are mostly linked to activities of local governments, as 3,178 local governments (Hungarian Central Statistical Office, HCSO, 2019) ensure the right to sports described in the Basic Law through local regulations, significant subsidies and, last but not least, maintenance of facilities. The operation of sports is usually carried out by the background institutions of local governments, their own companies, regular operation of which is in the interest of the state and local governments, but mostly of the citizens. Based on audit reports of State Audit Office, results of our study are about the companies dealing with sports background of Hungarian local governments. Keywords: local governments, sports affairs, State Audit Office, public service, background institution

\section{Bevezetés}

A Magyarország helyi önkormányzatairól szóló 2011. évi CLXXXIX. törvény (a továbbiakban: Mötv.) 13. $\$(1)$ bekezdése $^{1}$ a helyi közügyek, valamint a helyben biztosítható közfeladatok körében ellátandó helyi önkormányzati feladatok között nevesíti a sportügyeket. Emellett a törvény rendelkezik a kétszintű önkormányzatisággal rendelkező Budapestről is, a föváros feladatai között

${ }^{1}$ Ld. a hivatkozott szakasz 15 . pontját. 
említi meg a fóvárosi szintű sport és szabadidősportot $^{2}$, míg a kerületi önkormányzat feladatai között helyezi el a kerületi sport és szabadidősport támogatását ${ }^{3}$. Magyarország Alaptörvénye kimondja, hogy a helyi önkormányzat a helyi közügyek intézése körében törvény keretei között meghatározza szervezeti és működési rendjét ${ }^{4}$. Ennek megfelelően a helyi önkormányzatok számos módon gondoskodhatnak az önkormányzati feladataik, így a sportügyeik ellátásáról is. Alapvetően az állami feladatellátáshoz hasonlóan ez a saját szervezetrendszerük, szerveik, intézményeik útján, az általuk alapított gazdasági társaságok közremúködésével, vagy a feladatok kiszervezésével történik. Ugyanakkor a nemzeti vagyonról szóló 2011. évi CXCVI. törvény (a továbbiakban: Nvtv.) elóírja, hogy a helyi önkormányzat csak olyan gazdálkodó szervezetben vehet részt, amelyben felelőssége nem haladja meg vagyoni hozzájárulásának mértékét. ${ }^{5}$

Az önkormányzatok feladatellátásához számos közjogi kérdés kapcsolódik. Az Állami Számvevo"székről szóló 2011. évi LXVI. törvény (a továbbiakban: ÁSZtv.) alapján az Állami Számvevőszék (a továbbiakban: ÁSZ), mint az Országgyủlés legfőbb pénzügyi és gazdasági ellenőrző szerve, általános hatáskörrel végzi a közpénzekkel és az önkormányzati vagyonnal való felelős gazdálkodás ellenőrzését (Boros, 2019a). Stratégiája szerint az ÁSZ az önkormányzatok ellenőrzése során azok pénzügyi-gazdasági helyzetét értékeli, feltárja azok mủködésének kockázatait és az adott ellenőrzési helyszínt mindig objektív mutatórendszer alapján választja ki (Boros, 2019b). A dokumentum kiemeli azt is, hogy a hatékonyabb és eredményesebb közpénzfelhasználás érdekében az ÁSZ nem csak a szabályszerűségi, hanem a közpénzekből finanszírozott programok és projektek (beruházások) teljesítmény-ellenőrzését is előtérbe kívánja helyezni. ${ }^{6}$

Jelen tanulmányban azokat az önkormányzati tulajdonban álló gazdasági társaságokat vizsgáljuk, amelyek valamely önkormányzat sportügyeinek ellátásában játszanak szerepet. Tekintve, hogy a korábbi önkormányzati törvény ${ }^{7}$ is tartalmazta a sportjellegű önkormányzati feladatokat, a vizsgálatainkat egy objektív időponttól kezdtük, nevezetesen a sportról szóló 2004. évi I. törvény (a továbbiakban: Sporttv.) 2004-es hatályba lépésétől. A kutatásaink során minden olyan ÁSZ jelentést áttekintettünk, amely önkormányzati tulajdonban álló olyan gazdasági társaságok vizsgálatára irányult, amelyek a sportot, mint helyi közügyhöz kapcsolódó közfeladat ellátását látta el a vizsgált időszakban (2004. március 13. - 2020. június 30.). Ennek megfelelően tizenöt olyan gazdasági társaság tevékenységét tekintettük át, amelyek sportügyi önkormányzati feladathoz kapcsolódó tevékenységet láttak el (az alapítványi szervezeti formációkkal nem foglalkoztunk).

Végezetül szeretnénk megjegyezni, ahogy korábban már utaltunk rá, az ÁSZ az általunk vizsgált időszakban lefolytatott ellenőrzései nem fedik le az ország valamennyi önkormányzatai olyan gazdasági társaságainak a tevékenységét, amelyek sportjellegü önkormányzati közfeladatokhoz kapcsolódnak. Éppen ezért a tanulmányunkban név szerint nem is említjük az elemzett társaságokat, hanem a hiányosságokra, kockázatokra és az ÁSZ által megfogalmazott javaslatokra fókuszálunk.

\section{A helyi önkormányzatok sporttal kapcsolatos fel- adatai és azok ellátása}

A helyi önkormányzatok sporttal kapcsolatos kötelező feladatait a Sporttv. határozza meg a Sport XXI. Nemzeti Sportstratégiáról szóló 65/2007. (VI. 27.) OGY határozatban foglalt hosszú távú fejlesztési koncepciójára is figyelemmel, ami a sportolók fejlesztési sajátosságaira is kihat (Géczi, 2016). A Sporttv.-ben meghatározott helyi közügyek intézése körében a helyi önkormányzat - a törvény keretei között -önkormányzati rendeletet alkot. A Sporttv. ezzel összefüggésben akként rendelkezik, hogy a tízezernél több lakosú helyi önkormányzatok rendeletben állapítják meg a helyi adottságoknak megfelelően a sporttal kapcsolatos részletes feladatokat és kötelezettségeket, valamint a költségvetésükből a sportra fordítandó összeget. Ez azt jelenti, hogy a tízezernél kevesebb lélekszámú önkormányzatok számára ezekről a szabályozási tárgykörökről való rendeletalkotás csak lehetőség.

\footnotetext{
${ }^{2}$ Ld. az Mötv. 23. S (4) bekezdésének 8. pontját.

${ }^{3} L d$. a 23. $\mathbb{S}(5)$ bekezdés 17. pontját.

${ }^{4}$ Ld. az Alaptörvény 32. cikk (1) bekezdésének d) pontját.

${ }^{5}$ Nvtv. 9. $\mathbb{S}(2)$ bekezdés.

${ }^{6}$ Az Állami Számvevöszék hivatalos dokumentum rendszere 2011-tól. In.: https://www.asz.hu/storagelfiles/files/ASZ_strategialasz_strategia. pdf?:download =true (2020.06.20.).

${ }^{7}$ Ld. a helyi önkormányzatokról szóló 1990. évi LXV. törvény 8. S(1) bekezdését.
} 
A Sporttv. szerint a települési önkormányzat meghatározza a helyi sportfejlesztési koncepciót, és gondoskodik annak megvalósításáról, annak célkitűzéseivel összhangban együttműködik a helyi sportszervezetekkel, sportszövetségekkel, fenntartja és működteti a tulajdonát képező sportlétesítményeket, támogatja az iskolai testnevelés és sporttevékenység gyakorlása feltételeinek megteremtését valamint az iskolai sportkörök működéséhez, vagy az ezek feladatait ellátó diáksport-egyesületek feladatainak zavartalan ellátásához szükséges feltételek megteremtését. A sportfejlesztési koncepciónál kiemelt fontosságú a stratégia, melyben a sport értékei mellett a helyi sajátosságoknak kell hangsúlyosan megjelenniük. Ebben a dokumentumban kell meghatározni a verseny-, vagy a szabadidősportra fordított erőforrásokat is, ugyanakkor meg kell jegyeznünk, hogy nehéz különbséget tenni a verseny-, és a szabadidősport sportszervezeteinek menedzsmentfunkciói között (Zimányi és Géczi, 2019). A megyei és a fóvárosi önkormányzat ezeken a feladatokon túl segíti a területén tevékenykedő sportszövetségek müködésének alapvető feltételeit, közreműködik a sportszakemberek képzésében és továbbképzésében, segíti a sportági és iskolai területi versenyrendszerek kialakítását, illetve az e körbe tartozó sportrendezvények lebonyolítását, részt vesz a nemzetközi sportkapcsolatok építésében, valamint közreműködik a sport népszerüsítésében, a mozgásgazdag életmóddal kapcsolatos sporttudományos felvilágosító tevékenység szervezésében, illetőleg közreműködik a sportorvosi tevékenység feltételeinek biztosításában. Ezeket a feladatokat látják el a megyei jogú városi önkormányzatok is adottságaiknak megfelelően. ${ }^{8}$

$\mathrm{Az}$ önkormányzatok emellett saját teherbírási képességükhöz mérten további sportjellegű feladatokat is elláthatnak, mint például beilleszthetik a saját települési rendezvénytervükbe a települési szintủ sport ösztönzését, elismeréseket alapíthatnak a kiváló helyi sportolók számára, a saját eszközeikkel támogathatják a sportnak a települési lakosság életébe történő integrálását. Az önkormányzatok számára is fontos, hogy különbséget tudjanak tenni a sportjellegü feladatok ellátásánál a verseny-, és a szabadidősport között, esetleg külön költségvetési kerettel és feltételekkel. Az elért versenyeredmények és helyezések alapján, a kiváló helyi sportolók támogatása a versenysport területéhez, az egészségmegőrző programok és lépések elsősorban a szabadidősport témaköréhez tartoznak, míg a települési szintű sport ösztönzése ezek feletti, pozitív nemzetgazdasági célú és hatású is egyben.

Az említett önkormányzati, sporttal összefüggő feladatok ellátásához az önkormányzatok elsődlegesen a költségvetési törvényben és más, ágazati főleg sportági - jogszabályokban meghatározottak szerint, állami támogatásokban részesülnek. Ezeknek a feladatoknak az ellátása az önkormányzatok részéről, ahogyan említettük számos módon megvalósulhat. Ahogyan az már a bevezetőnkből kiderült, ezek a társaságok olyan feladatokat látnak el részben vagy teljes egészében az önkormányzatok helyett, amelyeknek elsődleges címzettje az önkormányzat. Ebből egyúttal az is következik, hogy az ÁSZ elsődlegesen azt vizsgálja a stratégiájában lefektetettekkel összhangban, hogy a helyi önkormányzatok, az államháztartáson kívülre nyújtott költségvetési támogatások és ingyenes vagyonjuttatások, valamint az államháztartáson kívül mủködő közfeladat-ellátó rendszerek átlátható, rendezett módon használják-e fel a közpénzt a közfeladatok szerződésben vállalt ellátása érdekében.

Az ÁSZ több jelentésében is megfogalmazta, hogy a közfeladat-ellátás tekintetében egyre jelentösebb a költségvetésen kívüli feladatellátás térnyerése, amelynek legfontosabb szereplöi - a nonprofit szervezetek mellett - az önkormányzati tulajdonú gazdasági társaságok. ${ }^{9}$

$\mathrm{Az}$ ellenőrzés rávilágíthat arra, hogy a vizsgált gazdasági társaság a feladat-ellátási, közszolgáltatási szerződésben foglaltak betartásával, a vagyon használatával biztosította-e a szolgáltatás folytatásának feltételeit, a feladat ellátását. Ezzel az ellenőrzöttek és a helyi döntéshozók számára visszajelzést ad feladatszervezési, feladat-ellátási kockázataikról, alapot ad a meglévő hibák megszüntetéséhez, a jobb feladatellátás biztosításához. A hibák javításával kapcsolatos kérdések megválaszolásához és a lehetséges módszerek megtalálásához a minőségmenedzsment tudományát lehet segítségül hívni. Általában hibaelemzésre van szükség, melyben a területre alkalmazható módszerek segíthetnek, mint Juran-céltáblája (a véletlen, statisztikai hibáktól az azonosítandó hibákon át a durva, egyedi hibákig.) Emellett hatékony módszernek bizonyulhat Ishikawa halszálka-diagrammja, vagy az ABC Pareto elemzés, amely elsősorban

\footnotetext{
${ }^{8}$ Ld. a Sporttv. 55. S-át.

${ }^{9}$ https://www.aszhirportal.hu/hu/jelentesek/az-agora-nonprofit-kft-ellenorzese-lezarult (2020.06.20).
} 
a nagyobb problémákra fókuszál és onnan halad az egyre növekvő számú, de kisebb fajsúlyú problémák felé (Topár, 2016). Természetesen a problémák besorolása, osztályozása nem egyszerü feladat, a télosznak megfelelően kell rangsorolni, azaz (a télosz alapján) a központi kérdés: mi a lényegi természete, mi a célja adott területen a hibaelemzésnek - ennek megfelelő lépések és módszerek kiválasztása.

\section{A helyi önkormányzati tulajdonú gazdasági tár- saságok sporttal kapcsolatos tevékenysége}

Az önkormányzati sportfeladatok ellátásban részt vevö társaságok tevékenységének ellenörzése

$\mathrm{Az}$ önkormányzati sportfeladatok ellátásban résztvevő társaságok (a továbbiakban együtt: Társaságok) közfeladat-ellátás megszervezésére vonatkozó döntésnek és annak előkészítésének, a jogszabályokban és az adott önkormányzat rendeleteiben foglaltakkal összhangban kell történnie. Az általunk vizsgált Társaságok szinte mindegyike $100 \%$-os önkormányzati tulajdonban állt a számvevőszéki vizsgálatok időpontjában. Egy olyan esettel találkoztunk, ahol a tulajdonosi joggyakorló valamilyen más, egyébként szintén 100\%-ban, önkormányzati tulajdonban lévő gazdasági társaság volt.

Ezeket a Társaságokat többnyire korábbiak átalakításával és kisebb részben újabb társaság alapításával hozták létre. Az elemzett Társaságok 90\%ban valamilyen közfeladat ellátása céljából kerültek átalakításra/megalapításra. Ez valójában tehát azt jelentette, hogy az alapításkori önkormányzati szabályozóknak megfelelően a helyi önkormányzatok valamilyen sporttevékenységgel összefüggő kötelező, vagy szabadon vállalt feladatukat a Társaságok útján látták el.

Az általunk elemzett Társaságok portfóliója igen vegyes, számos esetben a sporttípusú közfalatokon túl más társadalmilag fontos tennivalókat, így ifjúsági, létesítményüzemeltetési, programszervezési vagy közművelődési feladatokat is elláttak. A sportfeladatok ellátására egyes társaságok a korábbi években közhasznúsági keret-megállapodást kötöttek, míg a feladatellátást szolgáló vagyont vagyonkezelésbe adással bocsátották a helyi önkormányzatok a társaságok részére.

A már említett általános célok mellett az ellenőrzés célja az ÁSZ részéről elsődlegesen az volt, hogy az adott önkormányzat a jogszabályi előírások figyelembevételével döntött-e az ellenőrzésre kerülő közfeladat megszervezéséről; az önkormányzat, vagy amennyiben közé és az adott sporttevékenységhez kapcsolódó társaság közé beékelődött egy másik szervezet vagy gazdasági társaság - a tulajdonosi joggyakorló szabályszerüen gyakorolta-e a tulajdonosi jogokat. Emellett az ÁSZ azt is vizsgálta, hogy a gazdasági társaság közfeladat-ellátása bevételeinek, ráfordításainak elszámolása és vagyongazdálkodási tevékenysége megfelelt-e a jogszabályi, illetve a közszolgáltatási vagy vagyonkezelési szerződésben foglalt tulajdonosi elóírásoknak, valamint azok végrehajtása szabályszerü volt-e. Az ÁSZ a Társaságok müködése során azt is felmérte, vajon a gazdasági társaság kötelezettségállománya kockázatot jelent-e a működésre, illetve a közfeladat ellátására, valamint, hogy a közfeladatok átláthatósága és elszámoltathatósága érdekében biztosítva volt-e a közszolgáltatás díjának megalapozottsága szabályszerü önköltségszámítással.

Az ellenőrzések során az ÁSZ a nemzetközi standardokat tekinti irányadónak és határozza meg az ellenőrzési program ellenőrzési kérdéseit, az ellenőrzött időszakban hatályos jogszabályok és az ellenőrzésre vonatkozó szakmai szabályok, módszertanok figyelembevételével. Az ellenőrzés a kiválasztott, tulajdonosi jogokat gyakorló önkormányzatra, illetve az ellenőrzésre kijelölt gazdasági társaság felett tulajdonosi jogokat gyakorló szervezetre és az ellenőrzött gazdasági társaságra terjedt ki.

A vizsgálathoz általunk választott széles időspektrumban ( 195 hónap) az ÁSZ az általunk elemzett Társaságok 2011-2020 közötti tevékenységét vizsgálta. A tizenöt társaság létrehozásával és müködtetésével az önkormányzatok - döntő többségében - a sportjellegü közfeladatok teljes spektrumát látták el, de találkoztunk olyan megoldással is, amely során csak részlegesen került sor a sportjellegü közfeladatok gazdasági társaság bevonásával történő ellátására.

A Társaságok egy jelentős része kizárólag valamilyen sporttal összefüggő tevékenységet lát(ott) el. Ezek között a legjellemzőbb a sportlétesítmény üzemeltetése, fenntartása, müködtetése volt. A második legjellemzőbb tevékenységi kör valamilyen sporttevékenység támogatása, így különösen a szabadidő, a tömeg- és versenysport, valamint az utánpótlás-nevelési feladatok ellátása. Hasonlóképpen ebbe a csoportba soroltuk a különféle sportesemények szervezését, a helyi polgárok sportolási lehetőségének biztosítását, a sportversenyek szervezését, valamint a köznevelési intézményekben bevezetett „mindennapos testnevelés” támogatását.

Végezetül a vizsgált Társaságok portfoliójában 
számos olyan feladat is megtalálható volt, amely vagy kiegészítő tevékenységként, vagy önként vállalt önkormányzati feladat végrehajtásában való közreműködésként realizálódott. Ebben a körben olyan feladatokkal találkoztunk, mint a rehabilitációs, oktatási, nevelési, készségfejlesztési, az egészséges életmód segítését célzó szolgáltatások, rekreációs szolgáltatások, vagy éppen vállalkozási tevékenység keretében bérbeadási, hirdetési, illetőleg valamely sportág csapatának a menedzselése. Olyan megoldást is láthattunk, amelyben a második nagy csoport feladatai jelentek meg alaptevékenységként és a létesítményüzemeltetés önként vállalt feladatként kapcsolódott a társasági feladatkörhöz.

1. ábra. A Társaságok által ellátott sportjellegű (köz)feladatok Forrás: saját szerkesztés az Állami Számvevőszék hivatkozott jelentései alapján

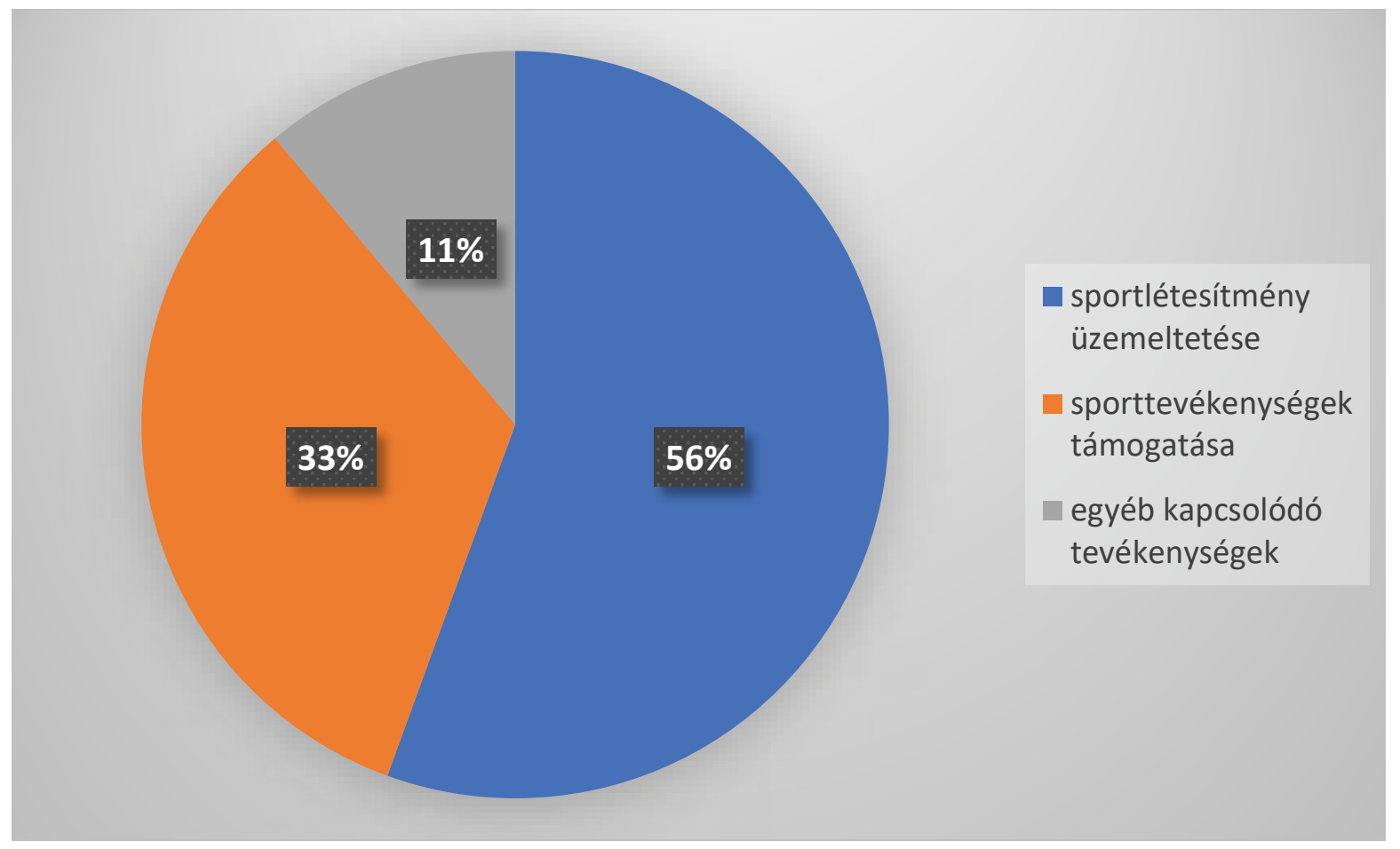

Lényeges elem az is, hogy a Társaságok egy része nem kizárólagosan valamilyen sporttal összefüggő tevékenységet lát(ott) el az ÁSZ által vizsgált időszakban: egyes társaságok ugyanis eleve a településüzemeltetés, vagy a különböző települési szolgáltatások rendszerébe integrált módon látták el a sporttal összefüggő feladatokat, vagyis a sportjellegü feladatok olyan feladatok mellett jelentek meg egyes önkormányzatok esetében, mint a közétkeztetés, a szociális intézmények működtetése, a fürdőüzemeltetési vagy éppen a kulturális feladatok (1. ábra).

Érdekességként azt is kiemeljük, hogy számos esetben a Társaságok fö tevékenysége ún. egyéb sporttevékenységként került megjelölésre. Ennek tartalmát pedig a kapcsolódó közszolgáltatási szerződésben rögzítette a tulajdonosi joggyakorló és az adott társaság.
A Társaságok által ellátandó feladatok tekintetében hangsúlyozandó, hogy azokat a Társaságok az önkormányzatok által meghatározott módon látják el. A sportjellegű közfeladatok tekintetében is fontos hangsúlyozni, hogy a feladatellátás szervezeti kereteitől függetlenül a (köz)feladat címzettje a helyi önkormányzat. Ahogy említettük, a tevékenység ellátás megfelelőségének ellenőrzése számos módon lehetséges, melynek egyik fontos vállfaja a tulajdonosi ellenőrzés. Az általunk vizsgált Társaságok egyharmadánál ez az ellenőrzési forma nem volt szabályos az ÁSZ jelentései alapján. A szabálytalanságok többféle hiányosságra vezethetők vissza: egyfelől a belső müködéssel kapcsolatos valamilyen szabályozó nemlétét, hiányosságát vagy intézkedés elmaradását állapította meg az ÁSZ, másfelől pedig a sportvagyon megfelelő hasznosítása kapcsán 
állapított meg hiányosságokat, különösen az Nvtv. 10. \$(2) bekezdésébe foglalt előírások ellenére a vagyonkezelésbe adott nemzeti vagyonnal való gazdálkodás ellenőrzésének elmaradására (2. ábra).

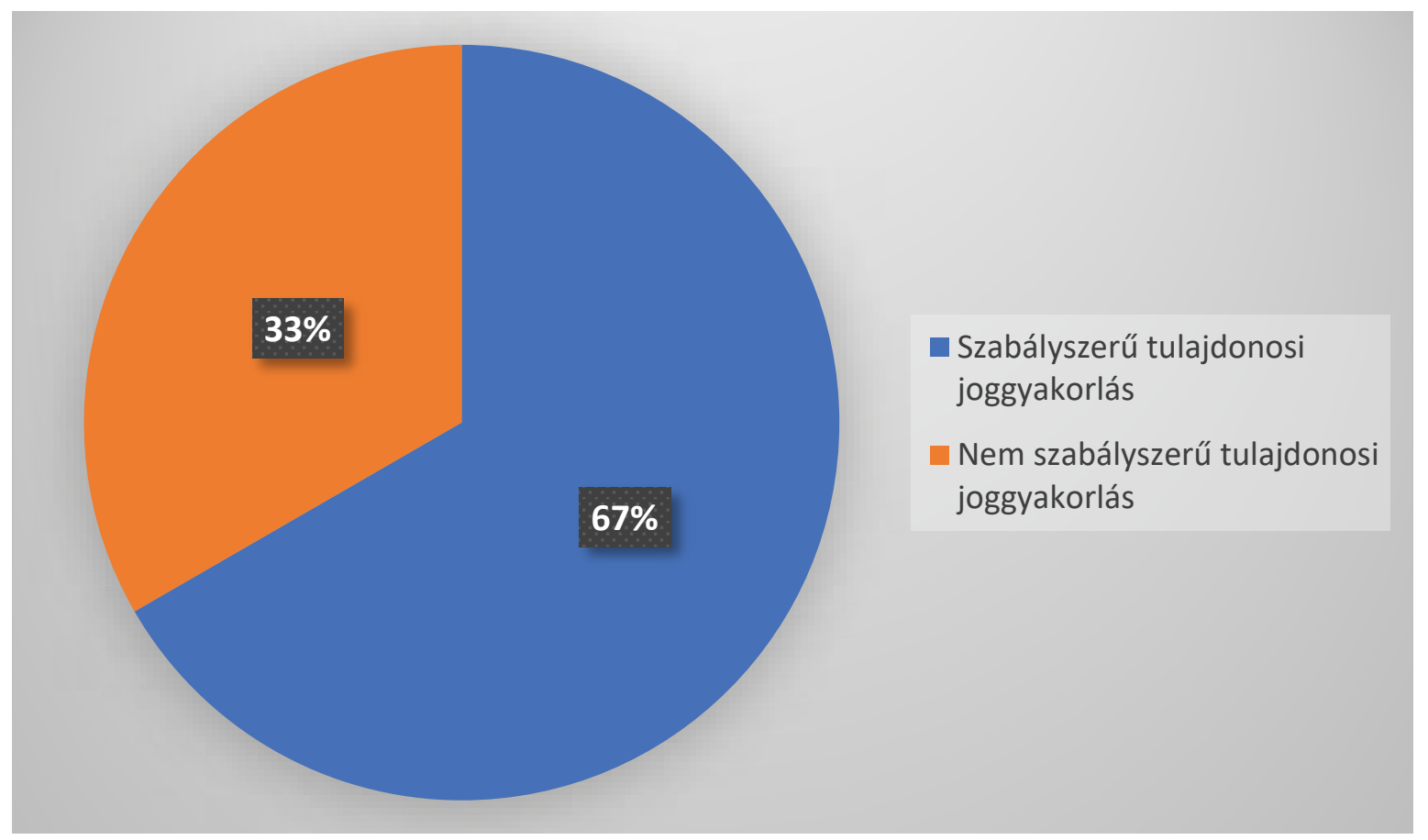

2. ábra. A tulajdonosi joggyakorlás szabályszerüsége Forrás: saját szerkesztés az Állami Számvevőszék hivatkozott jelentései alapján

Kérdésként merülhet fel, hogy vajon mit jelent valójában a „sportvagyon megfelelö hasznosítása”? A hasznosításhoz alapul vehetjük az utilitarista gazdasági és igazságosságelméleti megközelítést, amelynek alapja a boldogság és hasznosság maximalizálása. A hasznosítás szempontjából nem mindegy, hogy a verseny-, vagy a szabadidősportra fókuszálunk, az önkormányzati stratégia alapján milyen a tevékenységi jellegek közötti megosztás. Ezen megkülönböztetést és az ennek megfelelő pénzelosztást és indoklásaikat is érdemes lenne vizsgálni a jövőben. Az utilitarizmus mellett további igazságosságelméleteket is lehetne vizsgálni - és amelyek megegyeznek a sportvagyon hasznosítás törvényi feltételeivel és téloszával, azon elméletek a gyakorlatban is alkalmazhatók (Zimányi és Géczi, 2019).

A másik kérdés: mi alapján hasznosítsuk a sportvagyont? Ha a sportra társadalmi alrendszerként tekintünk, akkor a gazdasági érdekeknél fontosabb a társadalom, azaz a sportvagyon társadalmi hasznosítása (ide tartozik a „social discounts” vizsgálati témakör, amellyel jelen keretek között nem foglalkozunk, de megállapítható, hogy a sportvagyon ilyen típusú és célú hasznosítása össztársadalmi érdek és értékteremtő hatású).

Akármelyik (télosznak megfelelő) igazságosságelméletet választjuk, illetve akár gazdasági, akár magasabb társadalmi szinten nézzük a sportvagyon hasznosításának lehetőségeit, a lényeg, hogy a sport értékei mellett az Nvtv.-nyel összhangban kell lenniük.

\section{Az önkormányzati sportfeladatok ellátásban részt vevö társaságok által kezelt vagyon}

Az általunk vizsgált Társaságok és tulajdonosi joggyakorlóik sporttal kapcsolatos legfontosabb feladatai döntően valamilyen sportcélú beruházás lebonyolításához vagy sportlétesítmény üzemeltetéséhez kapcsolódnak.

Ezzel összefüggésben elengedhetetlen szólnunk röviden az önkormányzati vagyonnal való gazdálkodás néhány kapcsolódó - sokrétű szabályrendszeréről. Az Nvtv. alapján a helyi önkormányzatok tulajdonában álló vagyon az állami vagyon mellett a nemzeti vagyon részét képezi. Az önkormányzatok vagyona törzsvagyon, vagy üzleti vagyon lehet. $A$ 
törzsvagyon közvetlenül a kötelező önkormányzati feladatkör ellátását vagy hatáskör gyakorlását szolgálja, és amelyet az Nvtv. kizárólagos önkormányzati tulajdonban álló vagyonnak minősít, törvény vagy a helyi önkormányzat rendelete nemzetgazdasági szempontból kiemelt jelentőségű nemzeti vagyonnak minősít (ezeket forgalomképtelen törzsvagyonnak tekintjük). Emellett a törvény vagy a helyi önkormányzat rendelete korlátozottan forgalomképes vagyonelemeket is meghatározhat. Ilyen lehet például az Nvtv.-ben is megjelenő a helyi önkormányzat többségi tulajdonában álló, közszolgáltatási tevékenységet ellátó gazdasági társaságban fennálló, helyi önkormányzati tulajdonban lévő társasági részesedés (Boros, 2019c).

Az önkormányzatok kizárólagos tulajdonában álló nemzeti vagyon tekintetében speciális vagyongazdálkodási szabályok érvényesülnek. Az ilyen vagyonelemek ugyanis néhány kivételtől eltekintve nem idegeníthetók el és nem terhelhetôk meg, hiszen a nemzeti vagyon alapvetô rendeltetése a közfeladat ellátásának biztosítása, ideértve a lakosság közszolgáltatásokkal való ellátását és e feladatok ellátásához szükséges infrastruktúra biztosítását. Az Nvtv. alapelvi szinten leszögezi, hogy a nemzeti vagyonnal felelős módon, rendeltetésszerūen kell gazdálkodni. Ez a törvény olvasatában elsődlegesen azt jelenti, hogy az önkormányzati vagyongazdálkodás során törekedni kell a vagyon megőrzésére, értékének és állagának védelmére, rendeltetésének megfelelő, az önkormányzat mindenkori teherbíró képességéhez igazodó, elsődlegesen a közfeladatok ellátásához és a mindenkori társadalmi szükségletek kielégítéséhez szükséges, egységes elveken alapuló, átlátható, hatékony és költségtakarékos múködtetésére, értéknövelő használatára, hasznosítására, gyarapítására, továbbá a helyi önkormányzat feladatának ellátása szempontjából feleslegessé váló vagyontárgyak elidegenítésére (Hegedüs, Lentner és Molnár, 2019).

Ezeknek az elveknek, valamint a helyi önkormányzat vagyongazdálkodásának az Alaptörvényben megfogalmazott kötelezettségeinek az érvényre juttatása érdekében az Nvtv. 9. \(1) bekezdése előírja, hogy az önkormányzatok közép- és hosszú távú vagyongazdálkodási tervet kötelesek készíteni (Lentner és Hegedüs, 2019). Ebben a tervben célszerû rendelkezni többek között a sportcélú beruházások eredményeként létrejövő vagyontárgyakról is, illetve az önkormányzati tulajdonban álló gazdasági társaságok rendelkezésére bocsátott önkormányzati vagyon értékének megőrzése, növelése, eredményesebb múködtetése érdekében szükséges intézkedésekről. Emellett számos önkormányzat különböző távra szóló Testnevelési és Sportfejlesztési Koncepcióban határozta meg a sporttal kapcsolatos helyi célkitűzéseket és feladatokat.

A sportlétesítmények üzemeltetése tekintetében különböző típusú megállapodásban kerültek rögzítésre a konkrét létesítményekre lebontott feladatok, illetve a múködési célú támogatás átadásának szabályai, a vagyonkezelt ingatlanokkal kapcsolatos alapvetô feltételek. Ezek a normatív és egyéb szabályozók a Társaságok üzleti terveiben is megjelentek, alapvetően az adott önkormányzat által meghatározott tartalmi és formai követelményeknek megfelelően. A tulajdonosi joggyakorlás rendjét a képviselő-testület az önkormányzat szervezeti és múködési szabályzatában, valamint a vagyonrendeletében szabályozta. A sportcélú beruházások, létesítmények, illetve egyéb vagyonelemek tekintetében a helyi önkormányzatok vagyonrendeleti szabályai is hangsúlyosak. Az általunk vizsgált önkormányzatok felénél a vizsgálatok idején hatályban lévő vagyonrendeletek azt is előírták a gazdasági társaságok részére, hogy az éves beszámoló mellett félévenkénti beszámolót is készítsenek. Ezeket a beszámolókat vagy a helyi önkormányzat illetékes bizottsága, vagy képviselőtestülete értékelte. Emellett egyes önkormányzatok esetében erôteljesen megjelent az önkormányzat belső ellenőrzésének szerepe is, amely döntően a Társaságok gazdálkodási rendszerét és közfeladat ellátását vizsgálta.

A fentieken túl a korábbi és a hatályos önkormányzati törvény is előírja a gazdasági program készítésének szükségességét. ${ }^{10}$ Erre azért utalunk, mert a legtöbb általunk vizsgált önkormányzat gazdasági programja rendelkezett a sportvagyon céljáról, így főként a települési sajátosságokhoz igazodó verseny-, szabadidő, diáksport támogatásáról, valamint a fogyatékos sport területén tevékenykedők finanszírozásáról, illetve a sport és egyéb rendezvények lebonyolítása céljából a megfelelő létesítmények biztosításáról (Lentner, 2019).

Végezetül a sportjellegú feladatokhoz kapcsolódó vagyonelemekkel való megfeleló gazdálkodás ellenőrzésében a Társaságok belső ellenőrző szerveinek is kiemelt jelentősége van, különös 
tekintettel a felügyelő bizottságok, illetve a könyvvizsgálók szerepére. Természetesen emellett még számtalan belső szabályozó, szabályzat, önkormányzati rendelet határozott meg olyan előírásokat, amelyek a sportvagyon rendeltetésszerú és hatékony használatát, hasznosítását közvetlenül vagy közvetetten szabályozták.

Az általunk vizsgált Társaságok esetében a vagyon átadása legtöbbször vagyonkezelési szerződés formájában került biztosításra a helyi önkormányzat részérôl az adott Társaság számára, azonban találkoztunk haszonkölcsön, sőt megbízási szerződéses konstrukcióval is. A sportcélú feladatok ellátásához kapcsolódó vagyonelemek vonatkozásában is kiemelt jelentőséggel bír a kezelt vagyon szerződésszerū és a jogszabályokban meghatározottak szerinti nyilvántartása, ahogyan a rajta végrehajtott beruházások elkülönítetten történő nyilvántartása is.

A Társaságok vagyonkezelési gyakorlata szinte kivétel nélkül hiányosságokat tárt fel: a legtöbb társaság számviteli éves beszámolói nem tartalmazták a vagyonkezelésbe kapott vagyon értékét, vagy magát a kezelt vagyont. Jelentős hiányosságként jelentkezett a különböző vagyonelemek jogszabályszerú nyilvántartásához kapcsolódó szabályozók hiánya is, így különösen a kötelező számviteli szabályzatok, a leltározási szabályzat, a vagyon elkülönített nyilvántartására vonatkozó szabályozás, az adatvédelem és az adatnyilvánosság szabályozásának, illetve közérdekủ adatokkal kapcsolatos kötelezettségekre vonatkozó szabályozás hiányosságai.

A sportcélú vagyonelemek felújitása, állagmegóvása is nagyon fontos kérdéskör. Ezzel összefüggésben az ÁSZ a Társaságok közel felénél állapított meg valamilyen relevánsabb szabálytalanságot, és - néhány kivételtől eltekintve - a többi esetében is megfogalmazásra kerültek javaslatok a Társaságok vezető tisztségviselője számára. Az ÁSZ jelentéseiben elsődlegesen a Társaságok által ellátott közfeladat bevételeinek és ráfordításainak elszámolása kapcsán az önköltségszámítási szabályzat hiányosságaira, az ellátott közfeladat bevételeinek a könyvviteli nyilvántartásokban történő nem megfelelő kimutatására, az önköltség számítására és az árképzés nem szabályszerủ eljárására, illetve néhány esetben a beruházások, felújítások és az értékcsökkenés elszámolásának szabálytalanságaira hívta fel a figyelmet (3. ábra).

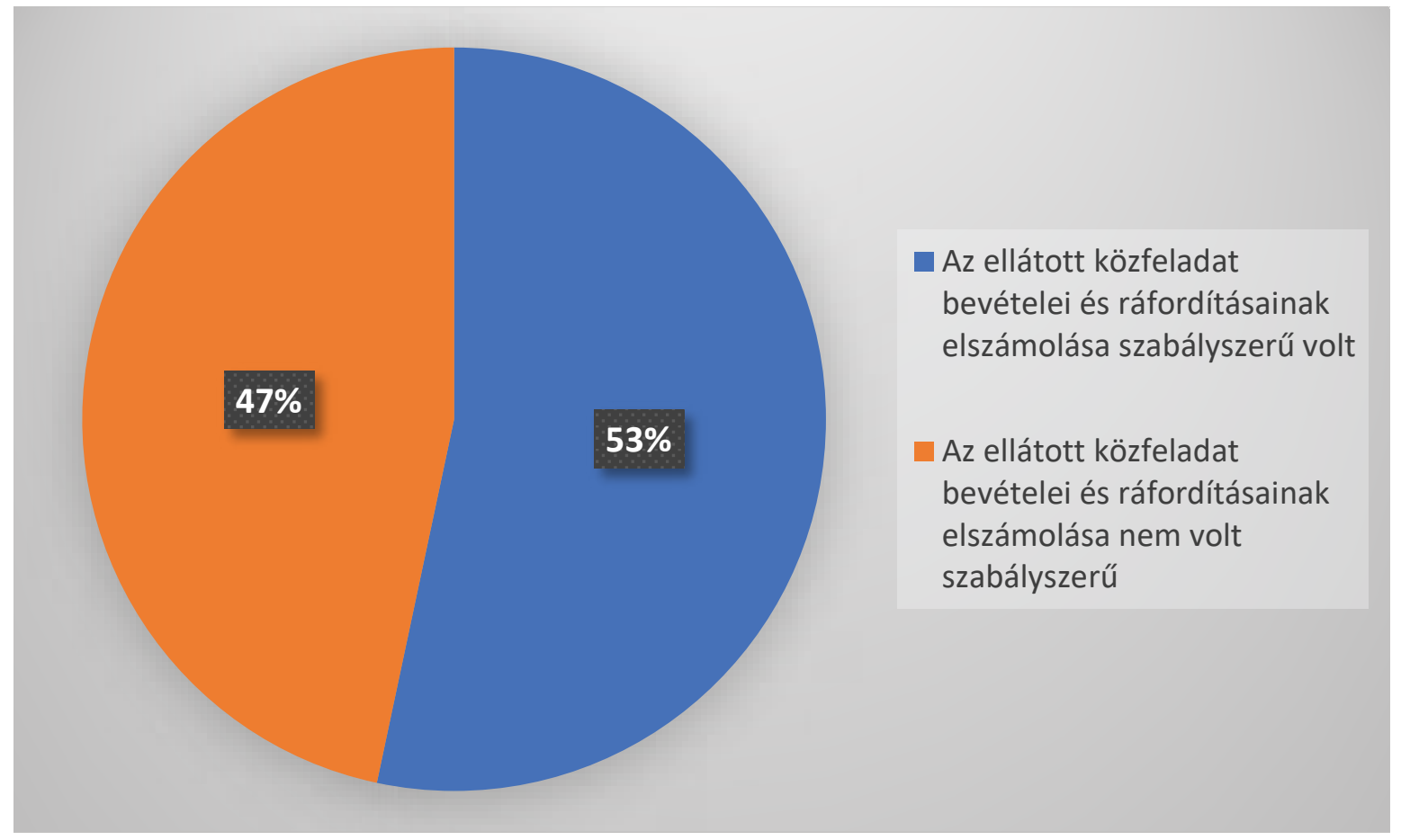

3. ábra. Az ellátott közfeladat bevételeinek és ráfordításainak elszámolása Forrás: saját szerkesztés az Állami Számvevőszék hivatkozott jelentései alapján 


\section{Az Állami Számvevőszék (ÁSZ) jelentéseiben megfogalmazott javaslatok}

Az ÁSZ jelentéseinek elemzése alapján megállapítható, hogy a legtöbb társaság működésének vizsgálata során a vagyonelemek megfelelő nyilvántartása és a közfeladat ellátáshoz kapcsolódó elszámolási kérdések jelentkeztek hiányosságként.
A Társaságok számára megfogalmazott javaslatok alapvetően az alábbi kategóriákba sorolhatók: a legtöbb javaslatot az ÁSZ az elszámolási renddel kapcsolatban fogalmazta meg, ezt követték a szabályozók hiányosságaival kapcsolatos javallatok, végezetül pedig az adatvédelmi és közzétételi kötelezettségre vonatkozóan megfogalmazott javaslatok (4. ábra).

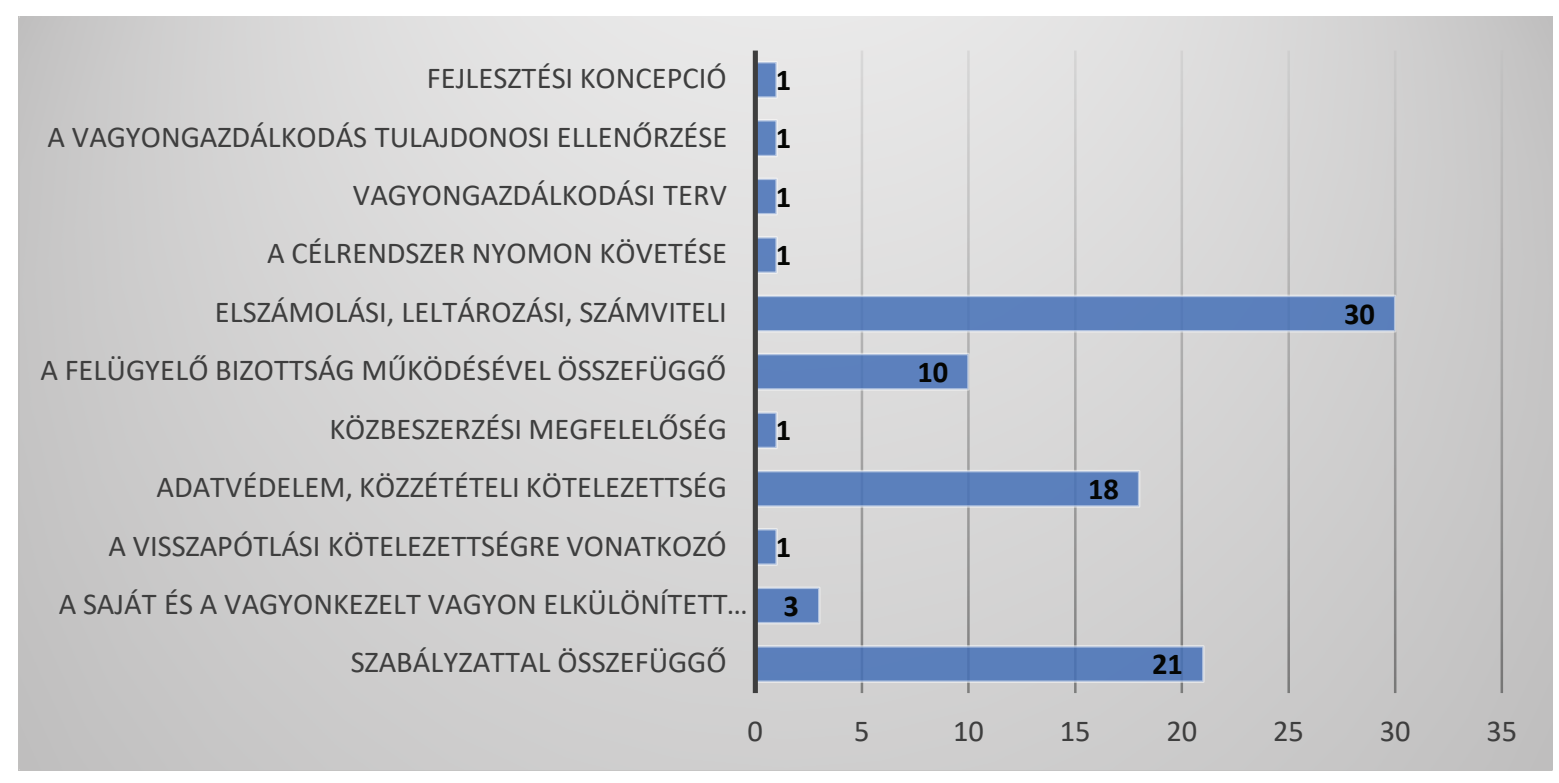

4. ábra. Az Állami Számvevőszék jelentéseiben megfogalmazott javaslatok Forrás: saját szerkesztés az Állami Számvevőszék hivatkozott jelentései alapján

A leírt javaslatok általában elfogadásra kerülnek a Társaságok működésével kapcsolatban, melynek következtében a vezetők korrigálják a hibás müködést.

\section{Összegzés, következtetések, javaslatok}

Cikkünkben a sport egy olyan területének kutatását kezdtük el, melyről kevés cikk jelenik meg a hazai sporttudományos szakirodalomban, ugyanakkor jelentős befolyással van a sportra. Sokak számára esetleg feleslegesnek tűnhet a hazánkban mủködő többszörösen biztosított, igen bonyolult mủködés-ellenőrző rendszer, azonban mint a vizsgálatban is bemutatott példák bizonyítják, mindig van mit fejleszteni, javítani a hatékonyabb működés érdekében. A hatékony mủködés hozzájárul a minőséghez, a minőségi folyamatok meglétéhez, melyek fenntartása komoly és fontos feladat. $\mathrm{Az}$ Állami Számvevőszék (ÁSZ) nyilvános vizsgálati jelentései olyan adatokat is tartalmaznak, melyek a sportgazdaság, a sportmenedzsment számára nagy jelentőséggel bírnak, hiszen általában pont a szabályszerűségi és gazdálkodási adatok érhetők el nehezen a területet kutatók számára.

Tanulmányunkban elsődlegesen összehasonlító módszertanokat alkalmaztuk és az ÁSZ jelentéseinek felépítéséhez igazodóan azonos ismérvek alapján hasonlítottuk össze a Társaságok mủködését. A kutatásaink rávilágítottak arra, hogy a vizsgált Társaságok igen heterogén közfeladat típusokat látnak el a tulajdonos önkormányzatok helyett. A Társaságok létesítő okiratainak vizsgálata alapján az is megállapítható, hogy ezeknek a feladatoknak a köre az elmúlt időszakban jelentősen bővült: ennek egyik oka egyfelől a közfeladat ellátásban bekövetkezett változások - néhol az állam és az önkormányzatok, esetenként a közfeladat ellátás rendjének változása nélkül egy-egy részfeladat állami koordinációjának erősödése mellett (pl. egyes támogatásból megvalósuló sportlétesítmények üzemeltetése) -, másfelől a szabályozási környezet változására visszavezethetően. A vizsgált Társaságok 
java része még a „régi” Polgári Törvénykönyv és a gazdasági társaságokra vonatozó külön törvény rendelkezései alapján kezdte meg a működését, az apportált, vagy a közfeladat ellátáshoz vagyonkezelési, üzemeltetési, vagy egyéb jogcímen rendelkezésre bocsátott vagyon használatát és hasznosítását. Azóta ezeket a kérdéseket teljesen új jogszabályok határozzák meg, ahogyan a helyi önkormányzatok gazdálkodását, a beszámolás rendjét, de jelentős fejlődésen esett át a sportjellegü közfeladatok helyi szintű szabályozási kereteit meghatározó joganyagunk is.

Ahogyan a fenti törvényekre való utalásokból is látszik, a sportügyekre vonatkozó szabályozás azonban nem keverendő össze a sport szabályaival (Róka, 2011). A szabályozási környezet változása mellett az elmúlt években a sportügyek és az ahhoz kapcsolódó ágazatok szakmapolitikai szinten is lényegesen hangsúlyosabbá váltak. A kormányzati döntések végrehajtása gyakran az önkormányzatok, azok szervei és nem utolsó sorban gazdasági társaságainak az aktív szerepvállalását is szükségessé tették.

Végezetül kiemelendő az is, hogy a magyar sportszektorban a finanszírozás területén is jelentős változások következtek be és a közösségi támogatás rendszere is jelentősen megváltozott (Gösi és Nagy, 2018). Az említett tényezők eredményeként a legtöbb Társaság tevékenységi körei bővültek, szélesedtek. A Társaságok működését vizsgálva azt látjuk, hogy azok képesek hatékonyan ellátni a rájuk bízott közfeladatot. A müködési problémák inkább abból erednek, hogy a rendelkezésükre bocsátott vagyonelemek rentábilis üzemeltetéséhez, fejlesztéséhez többnyire tulajdonosi donációra szorulnak. Ez a közfeladat ellátás körében nem ismeretlen jelenség, azonban a tulajdonosok jelentős része a vizsgált időszakban a továbbfejlesztésre nem tudott további forrásokat biztosítani. Hosszú távon ez a vagyonelemek elhasználódásához vezethet. Ugyanakkor a kutatásainkból az is kiderült, hogy a sportjellegű feladatok gazdasági társasági formában való ellátása rugalmasabbnak, a változó feltételekhez könnyebben alkalmazkodónak, egy-egy pályázati, vagy együttműködési lehetőségre hamarabb reagálni tudónak bizonyult. Reméljük, hogy tanulmányunk rávilágított néhány olyan összefüggésre, amely a helyi sportvállalkozások működése és működtetése szempontjából releváns lehet.

\section{Szakirodalom}

1. Géczi G. (2016): A Hosszú-távú Sportolófejlesztési Program szükségszerűsége a magyar sportban. Testnevelés, Sport, Tudomány. 1. évf. 1. sz. 27-37 p

2. Boros A. (2019): Compliance Audit Issues of State-owned Business Associations. Pénzügyi Szemle/Public Finance Quarterly. 4 pp. $542-$ 558., 17 p. (2019a)

3. Boros A. (2019): Az állami ellenőrzés egy sajátos válfaja, avagy a megfelelőség (compliance) és az integritás kérdésköre egyes közszféra szervezetek esetében. Pro Publico Bono: Magyar Közigazgatás; A Nemzeti Közszolgálati Egyetem KözigazgatásTudományi Szakmai Folyóirata. 2 pp. 4-27., 24 p. (2019b)

4. Boros A. (2019): IV. fejezet: A nemzeti (állami és önkormányzati) vagyonnal való gazdálkodás. In: Imre, Miklós (szerk.) Szakigazgatás I. Budapest, Magyarország: Nemzeti Közszolgálati Egyetem, Államtudományi és Közigazgatási Kar, pp. 66-83., 18 p. (2019c)

5. Gősi Zs. és Nagy J. (201): Sportvállalkozások gazdasági adatai a megváltozott finanszírozási környezetben. Testnevelés, Sport, Tudomány. 1-2. sz. 61-72 p

6. Hegedűs Sz., Lentner Cs. és Molnár P. (2019): Múlt és jövő: az önkormányzati (vagyon) gazdálkodás új útjai az adósságkonszolidációt követően: Fókuszban a megyei jogú városok. Pénzügyi Szemle/Public Finance Quarterly 64: 1 pp. 49-69., 21 p.

7. Központi Statisztikai Hivatal (2019): Magyarország közigazgatási helynévkönyve. Budapest.

8. Lentner Cs. és Hegedüs Sz. (2019): Az önkormányzati tulajdonú gazdasági társaságok szerepe a feladatellátásban - az állampénzügyi menedzsmentbe ágyazottság szemszögéből. Jura 25 : 1 pp. 357-366., 10 p.

9. Lentner Csaba (2019): Önkormányzati pénzés vagyongazdálkodás. Budapest, Magyarország: Nordex Nonprofit Kft. - Dialóg Campus Kiadó, 167 p.

10. Topár József (2016): Minőségmenedzsment oktatási segédanyag. BME GTK ÜTI, Budapest. 
11. Róka G. (2011): A sport autonómiája. Sportszektor és közösségi jog. Iustum Aequum Salutare VII. 2011/1. · 123-131.

12. Zimányi R. G. és Géczi G. (2019): Sportszervezetek és menedzsmentfunkcióik elmélet és gyakorlat

13. Minöség és Megbizhatóság $53: 4$ pp. 400406., 7 p.

14. Zimányi R. G., és Géczi G. (2019): The Justice of the Grand Slam Tennis Tournaments on the Basis of Draw, Competition Format System and Final Result: a Case Study of the US Open 2017 Men's Singles Tournament, Physical Culture and Sport Studies and Research 83:1 pp. 26-38.

\section{Jogszabályi hivatkozások}

1. Magyarország Alaptörvénye

2. 2011. évi CLXXXIX. törvény Magyarország helyi önkormányzatairól

3. 2011. évi CXCVI. törvény a nemzeti vagyonról

4. 2011. évi LXVI. törvény az Állami Számvevőszékről

5. 2004. évi I. törvény a sportról

6. 65/2007. (VI. 27.) OGY határozat. a Sport XXI. Nemzeti Sportstratégiáról 